\title{
Health in all policies - health of the population in development policies in Poland, with particular focus on health inequalities
}

\author{
Zdrowie we wszystkich politykach: zdrowie populacji w politykach rozwoju \\ w Polsce, ze szczególnym uwzględnieniem społecznych nierówności \\ w zdrowiu
}

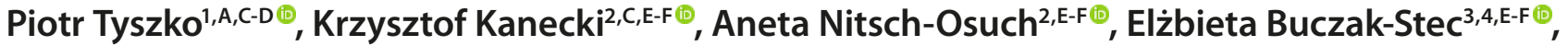 \\ Magdalena Bogdan ${ }^{2, C-D \circledast}$ \\ ${ }^{1}$ Institute of Rural Health, Lublin, Poland \\ ${ }^{2}$ Department of Social Medicine and Public Heath, Medical University, Warsaw, Poland \\ ${ }^{3}$ National Institute of Public Heath, Warsaw, Poland \\ ${ }^{4}$ Department of Health Economics and Health Services Research, University Medical Centre Hamburg-Eppendorf, Germany \\ A - Research concept and design, B - Collection and/or assembly of data, C - Data analysis and interpretation, \\ $D$ - Writing the article, $E$ - Critical revision of the article, $F$ - Final approval of article
}

Tyszko P, Kanecki K, Nitsch-Osuch A, Buczak-Stec E, Bogdan M. Health in all policies: health of the population in development policies in Poland, with particular focus on health inequalities. Med Og Nauk Zdr. 2021; 27(1): 54-59. doi: 10.26444/monz/133410

\begin{abstract}
Introduction. Creating an impact on health is a long-term process that involves activities of public policy. In Poland, particular policies are formulated in documents at the central, regional and local levels. The presence of health issues in these documents can be a measure of the involvement of various sectors in health protection, and thus a measure of the implementation of health principle.in all policies.

Objectives. The aim of the study is to compare the health issues and health inequalities in policy documents.

Materials and method. Study methodology included an analysis and review of documentation. The review covered official documents of government bodies in which central, regional and local policies, accepted for the implementation in 2007-2013 and 2014-2020, were formulated.

Results. An analysis of 121 documents formulating development policies provided information about health issues and health inequalities in central, regional and local policies. Health inequality issues was identified in 12 health policy programmes implemented by the Ministry of Health. Conclusions. Although health issues and health inequalities are present in all documents formulating public policies, they were given the biggest attention in the documents at the central level. It was observed that the level of health inequality representation in the strategies of provinces was very low, in the strategies of counties, it was marginal. Certain activities aiming at the increase in the awareness of health inequality should be undertaken.
\end{abstract}

\section{Key words}

health in all policies, strategic planning, health policy, health inequality

Address for correspondence: Magdalena Bogdan, Department of Social Medicine and Public Health, Medical University, Warsaw, Poland

E-mail:mbogdan@wum.edu.pl

Received: 21.11.2020; accepted: 15.02.2021; first published: 24.02.2021

\section{Streszczenie}

Cel pracy. Wpływanie na zdrowie jest procesem długofalowym i wymaga aktywnej polityki społecznej. W Polsce takie polityki formułowane są na poziomie centralnym, regionalnym oraz lokalnym, czemu służą odpowiednie dokumenty. Zawarta w dokumentach tych istota zagadnień zdrowotnych może być miarą zaangażowania różnych sektorów w opiekę zdrowotną, a tym samym - miarą wdrażania reguł koncepcji „Health in All Policies". Celem poniższego badania jest analiza komparatywna obecności zagadnień i nierówności zdrowotnych w dokumentach programowych.

Materiał i metody. Wykorzystane metody badawcze skupiają się na analizie dokumentów. Praca zawiera analizę programowych dokumentów rządowych tworzonych na szczeblu centralnym, regionalnym oraz lokalnym, które zostały przyjęte do realizacji w latach 2007-2013 oraz 2014-2020.

Wyniki. Analiza porównawcza 121 centralnych, regionalnych oraz lokalnych dokumentów programowych pozwoliła przedstawić omawiane zagadnienia i nierówności zdrowotne. Zagadnienia oraz nierówności zdrowotne zostały zidentyfikowane w 12 dokumentach programowych wdrożonych przez Ministerstwo Zdrowia.

Wnioski. Pomimo że zagadnienia zdrowia oraz nierówności w zdrowiu są zawarte we wszystkich dokumentach programowych, to największy nacisk na tę materię położono w dokumentach na poziomie centralnym. Dało się zaobserwować, że na poziomie strategii województw problematyce nierówności zdrowotnych poświęcona jest niewielka uwaga, a w polityce na poziomie powiatowym tylko marginalna. Należałoby podjąć jeszcze szereg inicjatyw zmierzających do podniesienia świadomości nierówności zdrowotnych.

\section{Słowa kluczowe}

polityka zdrowotna, planowanie strategiczne, zdrowie w programach politycznych, społeczne nierówności w zdrowiu 


\section{INTRODCTION}

Creating an impact on health is a long-term and complex process that involves activities in many areas of public policy, in particular education and social policies. Even those policies which seem to be unrelated to health issues, such as those concerning the development of industry or transport, have a direct influence on the health of the population through various mechanisms, including human pressure on the natural environment, and social impact. Similar circumstances exist in the case of social and geographical health inequalities. Although health policies are being shaped mostly by the health situation of the population, formulating the policy means determining the priorities and methods to improve the health condition. This formulation is limited by a number of factors, among them demography, economy, and the potentials and organization of health care. These factors can be recognized as internal determinants, but the national health policies are equally determined by external factors linked to e.g., realization of international and legal commitments related to fighting the spread of infectious disease. National health policies should also take into consideration other, non-legal, multi- or bi-lateral commitments, such as declarations or programmes - The Millennium Development Goals or Clustering of Essential Public Health Operations (EPHOS).

Similar in nature is the Health in all Policies Declaration the implementation of which is at core of this article. The impact of such an international declaration on the shaping of the health policies on the central, regional and local level, has not yet been researched. According to the definition by J. Indulski [1], health care means 'all social activities aimed at the prevention and treatment of diseases, stimulating psychological, physical and social development of a human, prolongation of life, development of new generations and improvement of the properties of human kind.' This definition describes both targets and a wide range of activities - 'all social activities' - for health. It can be argued that the Health in All Policies [2] (HiAP) approach is a contemporary development of the health care understanding presented above. A breakthrough in the approach to the institutionalization of Health in All Policies came in 2007 at a conference in Rome, during which 27 health ministers of the European Union member states [3], including the Health Minister of the Republic of Poland, adopted a special declaration.

Development planning in Poland on the central and regional level is regulated by law [4]. All elements of the structure of this strategic document are legally defined and in accordance with the rules of strategic planning [5], including, e.g. situation diagnosis, forecast of development trends for the strategic period, definition of strategic objectives of the development policy.

The issues of health of the population, including health inequalities, are included in documents that concern this sphere of social policy, as well as in the documents that cover other areas of development. It can be assumed that the presence of health issues in other policies than the health policy is one of the outcomes of the implementation of Health in All Policies concept.

\section{OBJECTIVES}

Specific objectives of the study were:

- comparison of the presence of health issues in documents formulating general and sectoral public polices at the central, regional and local level in two periods - 2007-2013 and 2014-2020;

- comparison of the presence of health inequality issues in the documents formulating public policies at the central, regional and local level in 2007-2013, and since 2014;

- identification and assessment of health inequalities in health policy programmes of the Ministry of Health of the Republic of Poland.

- characterization of the content of diagnoses and the goals of strategies at different levels of planning.

It should be noted that the documents concerning development policy for the years 2007-2013 were developed before 2007, that is before the adoption of Health in All Policies Declaration, whereas the currently binding documents were developed after the adoption. It is worth noting that the implementation of the Health in All Policies strategy in Poland was not subjected to organized activities, as those opposed to, e.g., Bulgaria [6] or Norway [7].

The presented study is the first analysis of the implementation of the HiAP strategy in Poland.

\section{MATERIALS AND METHOD}

Study methodology included a documentation analysis. Two groups of documents were identified among domestic documents formulating policies at the central regional level: (i) from 2007-2013 and (ii) binding in 2014-2020.

Documents formulating national policies were found on the official websites of particular ministries, which were relevant in 2007 and 2014 (Appendices 1 and 2). Policy paper dla ochrony zdrowia na lata 2014-2020 - Krajowe Ramy Strategiczne, which was essential in order to launch the funding of structural funds and the Cohesion Fund, has not been considered in the analysis. The policy paper is of secondary character when juxtaposed with national strategic documents concerning health policies, and are incapable of formulating original diagnoses or health policies objectives. Regionally strategic documents were found on the websites of Marshals' Offices and Provincial Offices (Appendices 3 and 4).

Locally strategic documents were identified on the official websites of counties (a second degree unit of local self-government covering part of the provincial area.) (Appendix 5).

In the case of documents formulating policies at the local level - development strategies of counties, only randomly selected up-to-date documents were analyzed, due to the fact that development planning at the local level does not stipulate uniform rules concerning the planning time (year-to-year), or the planning period number of years subject to planning), which results in a high diversity. In total, 266 documents concerning local development policies were identified on the websites of 379 counties. Three county strategies from each county were randomly selected for analysis of the presence of health issues, a total of 48 documents, which constituted $18.05 \%$ of all identified documents. The list of health policy 
programmes of the Ministry of Health included in the analysis is presented in Appendix 6.

All documents were subject to a praxeometric analysis. Two types of elements - indicators for health issues and health inequalities - were searched for in the documents, including information on particular policies, diagnosed as a basis for setting objectives and defined objectives. An analysis of the quality of planning in Poland showed that objectives can be found in different and difficult to foresee places in the strategic documents. Two techniques were used to precisely identify two important elements of the strategy plan, namely, diagnosis as a basis for setting objectives and defined objectives. The first technique is the analysis (reading and identification of public health objectives and reducing inequities in health) in those parts of strategic documents that formally address situation diagnosis, and definition of strategic objectives of the development policy. The second technique involves searching for entries on the basis of key words in the other parts of the strategic document, using the FIND function (Ctrl $+\mathrm{f}$ in Microsoft Word and Adobe Acrobat Reader DC). The key words were: health, health care, health status, prevention, prophylaxis, disease, inequalities, health inequalities. The identified entries were included if they fell under the logical context of the words: goal, aim, objective, target, and if they occurred in the descriptive wordings with the meaning how something should be achieved, performed, etc. The total volume of the analyzed documents was about 8,000 pages in each of the two planning periods.

\section{RESULTS}

The analysis covered 121 documents formulating policies that refer to health and health inequality at the national, regional and local level. Among these documents there were 34 documents at the central level, 39 at the regional level, and 48 at the local level.

Health issues in the documents formulating public policies. Health diagnoses were found in $22.2 \%$ of the central documents in 2007-2013, and $27.3 \%$ of documents that have been binding since 2014 , whereas health objectives were found in $18.5 \%$ and $27.3 \%$ of those documents, respectively.

Health issues, in the form of health condition diagnoses or health-related objectives, were present relatively more frequently in the documents referring to regional development policies. $40.9 \%$ of the regional documents in 2007-2013 and $23.5 \%$ of the currently binding documents included health objective diagnoses, whereas health objectives were included in $36.4 \%$ and $47.1 \%$ of those documents, respectively. Health condition diagnoses were least frequently included in local policies - only in $4.2 \%$ of the documents, and heath objectives were present only in $8.3 \%$ of those documents.

A substantive analysis showed that health issues were most frequently included in the documents formulating general development policies. However, they are ignored in the documents concerning directional policies, especially those policies which refer to technology, e.g. transport or energy development. It is noticeable that more than half of regional strategies formulating general development visions fail to include health issues.
In the planning period 2007-2013, a half of the health diagnoses, which are the base for the formulation of objectives at the central level, generally described a bad, unfavourable and unsatisfactory health condition, and included illnesses, such as cardiovascular diseases, cancer, infectious, and mental illnesses. Health diagnoses in the documents at the central level were usually based on the comparison of the mortality and life expectancy rates, with reference to the European Union.

Health objectives were defined generally as health improvement, and in one case as a limitation of the effects of accidents and other hazards. At the same time, however, health goals which were formulated in this way took a relatively high position in the hierarchy of goals. In the analyzed strategies, health objectives were an element of the main objectives, or they constituted an intermediate target of the first stage.

In the planning period after the year 2014, population health diagnosis in the documents formulating the strategy at the central level is most fully referred to in the National Development Strategy 2020. This is based on the data on increasing life expectancy of men and women in Poland, including the healthy life years (HLY) and life expectancy (LE) indicators. The diagnosis was 'Poles live longer, but their health condition is worse.' Public health objectives were addressed best in two documents: the National Development Strategy 2020 and the Human Capital Development Strategy 2020. It is worth noticing that the health improvement objective is a part of a broader goal - the improvement of the quality of life. The documents also stress the importance of health for the quality of human capital and labour market activity.

Health diagnoses in the documents formulating development strategies at the regional level indicated problems in the specific groups of diseases, mostly cardiovascular diseases and cancer, and in individual cases of infectious diseases, tuberculosis and mental diseases. Incidentally, health diagnoses referred to the populations of infants, children and those employed. Health objectives at the regional level were formulated in a very general way: health improvement, health condition improvement, improvement of health situation, healthy society, limitation of the incidence of the diseases of affluence.

Only a few diagnoses included in the documents formulating local development strategies referred to selected adverse indicators of the health of the population. The goals at this level of planning are formulated in a general way, e.g. health improvement, good health, improvement of health status, safe and healthy residents. These goals have different ranks in the hierarchy of the objectives of individual strategies.

Health inequality in documents formulating public policies. Health inequality in the current policies at the central level is given equal attention as health issues. However, it is very rarely included in regional documents - only in 5\% of the documents, and it is ignored in the local documents.

The above-mentioned data show that the representation of health-related issues in the documents concerning policies formulated at the central level, in the current planning period has increased, compared with the period 2007-2013. In addition, an increase in the number of objectives in regional development policies was observed. At the same 
time, a decrease in the number of health condition diagnoses, which are a basis for setting the objectives, was noted.

Health inequality, understood as a phenomenon diagnosis, was present in $11.1 \%$ of central policies from the previous planning period, and $27.3 \%$ of the currently binding policies. Inequality-related objectives were included in $3.7 \%$ and $27.3 \%$ of the documents formulating policies, respectively. In both studied planning periods, an analysis of the documents formulating regional level policies showed no presence of health inequality diagnoses, as a structural element of the documents. However, inequality-related objectives were found in $4.6 \%$ of the documents from 2007-2013, and in $5.9 \%$ of the currently binding documents. A study in the development strategies for the counties showed no record of health inequality-related diagnoses or objectives.

In the documents formulating central development strategies in the 2007-2013 planning period, territorial differences in the population's health situation were diagnosed, including inequities in the health of pregnant women, infants, children and adolescents. The only specific objective at this level of planning, which regards reducing inequalities in health, concerned women of childbearing age, newborns and infants.

Only a few goals, which were formulated in the discussed period at the regional level, concerned the adjustment of healthcare buildings and facilities to the current standards, in order to reduce differences in health and access to specialized health services.

In the planning period after the year 2014, the documents formulating central development strategies indicated the presence of inequalities in health. On the basis of data from the World Health Organization report [8], it was concluded that there is insufficient progress in the implementation of cross-sectoral measures aimed at the reduction of social inequalities in health, including preventive activities and promotion of healthy lifestyle. The objectives in the field of inequalities in health included improvement of access to health services, in particular life-saving procedures, highly specialized services (e.g. organ transplantation), oncological treatment services, treatment of rare diseases, and better access to blood and blood components, thus ensuring the selfsufficiency of Poland in terms of blood. It was also planned to undertake cross-sectoral activities aimed at the reduction of health inequalities resulting from social conditions, including the intensification of preventive measures promoting healthy lifestyle and combating harmful behaviurs, such as smoking, alcohol abuse, improper diet and lack of physical activity. At the regional level, the only goal that was formulated as 'reduction of inequalities in health' was an element of goals of the higher level - improving the quality of life of residents

Incorporation of health inequality in health policy programmes of the Ministry of Health. In the health policy programmes of the Ministry of Health, health inequality is addressed only in the National Programme of Transplantation Medicine Development, where references to Objective 8 of the National Health Programme 2007-2015 are made. This objective concerned the 'Reduction of social and territorial differences in the health condition of the population' [9].

\section{DISCUSSION}

The current study compares the presence of health issues and health inequality issues in documents formulating public polices in two periods, 2007-2013 and since 2014. The study also identifies and assesses health inequalities in the health policy programmes of the Ministry of Health of the Republic of Poland. Analysis showed an increase in the representation of health inequality issues in the documents from the currently binding planning period, compared with the documents from 2007-2013. While this increase is significant for objectives, it is slightly lower for inequalityrelated diagnoses included in the central-level documents. The level of addressing health inequality in the planning of the development at the regional and local levels, both in the previous and in the current planning periodwais minimal. This situation is highly unfavourable due to the fact that one of basic determinants for inequalities are factors of a local character, and intervention at this level belongs to strategic rules for health inequality reduction.

The observed differences can be interpreted as a measure of the increase in the implementation of health in the principle of all policies. It is worth mentioning that strategic documents for 2007-2013, were developed before 2007, before the adoption of Health in All Policies, whereas the documents which have been binding since 2014 were developed after the adoption of the declaration. Nevertheless, the increase in the representation of health issues seems to be insufficient with reference to the assumptions of the Health in All Policies concept. The phenomenon of a very low level of addressing health issues in strategic plans for county development can be assessed as decidedly unfavourable. The low level of interest of local self-governments in health issues might be an effect of the currently binding rules of the organization of health care in Poland. In this model of contracting medical services, decisions about the type and location of outpatient medical facilities are made by the National Health Fund. These decisions are made on the basis of evaluation criteria developed by the Ministry of Health, but without the involvement of the local government.

It is worth noting that in the main documents describing development policies at the central level, health is not referred to as an autotelic value, but as one of the areas of complex understanding of quality of life (Poland 2030. Third wave of modernity. Long-term National Development Strategy), or as an element of the improvement of the quality of human capital (National Development Strategy 2020). However, in the regional and local strategies, health is often understood as an autotelic value.

It would be interesting to compare the effects of the implementation of the HiAP strategy in Poland and in other countries, where relevant reports on this subject are available, e.g. Bulgaria or Norway. The main difference between the situation in Bulgaria and Poland is that since 2015, a special programme, Bulgarian Partnership for Health, has been operating in the first of the two countries. While it is 'an important step towards an improved health policy process' in Bulgaria [6], the implementation of the HiAP strategy in Poland was more spontaneous. This does not mean that the state activities in Poland do not include mechanisms that favour cross-sectoral activities for the benefit of public health. One example of such mechanisms is the legislative process involving cross-sectoral consultations. Another example 
is the development and implementation of the National Health Programme 2016-2020, which is a cross-sectoral task. Comparison of the activities in Poland and Norway is limited due to the differences in health care systems of these countries. While institutions at the local level in Norway are very important for the development and implementation of health policies, health policy in Poland is formulated at the central level, and its transfer to the local level is not effective enough, as demonstrated by the research $[9,10]$.

A qualitative analysis of the content of the diagnoses and directions of the established goals indicates several problems. Health diagnoses that are a base for the formulation of strategic goals at the central level of planning are of a more general character than those used at the regional level. The diagnoses contained in the documents from 2007-2013 describe healthrelated phenomena, mostly using comparisons: good - bad, better - worse. Specific epidemiological indicators of health status are rarely referred to. It is worth noting that public statistics surveys conducted in Poland are a base for calculating the number of demographic and epidemiological indicators. In the 2014-2020 planning period, objective indicators and their comparisons with the average indicators for the European Union, are used more often, although they are still not fully used in diagnoses. The difference in the formulation of diagnoses contained in the strategic documents shows that there is an improvement in the quality of the development of strategic documents at the central level. This change, however, cannot be linked to the implementation of the Health in all Policies strategy, but it is rather a result of the increased experience of government authorities responsible for strategic planning. In the case of strategic documents at the regional level, no such phenomenon was observed.

An analysis of the goals set in the development strategies at the central level indicates that the objectives related to public health constitute an element of broader goals, such as improvement of the quality of life and the quality of human capital. This position of health objectives may result in their marginalization during the implementation of particular strategy plans. In this context, it seems important to call for careful monitoring of the implementation of various strategies that include elements of health objectives, with reference to activities aiming at health improvement and reduction of social inequalities in health. In this process, an important role should be played by the minister responsible for health matters, as well as social organizations and scientific societies acting in the field of public health.

In the face of the presented situation, it is an important task to increase the awareness of health inequalities and the necessity to overcome this phenomenon among selfgovernment activists, as well as regional and local selfgovernment administration staff. It is necessary to develop a general methodology and specific tools to reduce social health inequalities and provide them to structures responsible for the organization of health care at the local and regional level. In recent years useful materials have been prepared and published, such as the Atlas of population mortality in Poland in 1999-2001 and 2008-2010 [11] and studies, such as Poviats at risk of deprivation: state, trends and forecast [12], Social health inequalities in children and teenagers in Poland in the light of populations studies [13], etc.

\section{CONCLUSIONS}

Health issues are represented in the current, most important documents formulating development policies at the central level, and are understood as an element of the quality of life or the quality of human capital, not as an autotelic value.

Health issues are addressed in less than half of general regional development strategies and they appear very rarely in the documents at the local level, which can be assessed as insufficient for the implementation of the objectives of the public health policy. Health inequality is represented in the currently binding strategic documents at the central level to a greater extent than in similar documents from the planning period 2007-2013; however, the level of the representation of this problem seems to be insufficient in the light of the stipulations of the Health in all policies declaration adopted by Poland.

After the Rome Declaration (2017), the increased appearance of health issues in all policy documents, the observed phenomenon suggests an increased awareness of the importance of a comprehensive approach to health policy in the formulation of state development policies, which is in line with the intent of the Rome Declaration.

The low level of representation of health issues in the development strategies for counties, and an even lower level of the representation of health issues in the development strategies for the provinces, seems to be alarming phenomenon from the perspective of the implementation of the objectives of public health policy.

The very low level of representation of health inequality in the development strategies for the provinces, and the marginal level of health inequality in the development strategies for counties, require implementation of activities aimed at an increase in awareness of the importance of health issues among self-government activists and self-government administration staff.

The development of methodology and tools for activities aimed at the reduction of health inequalities, and providing them to institutions responsible for health care at the regional level and local level in particular, are recommended.

The introduction of institutional and social supervision of the implementation of strategic plans in the field of health and social inequalities in health are also recommended.

\section{Key points}

- Health issues are represented in the most important documents formulating development policies.

- After the Rome Declaration, there was an increased appearance of health issues in all policy documents.

- Health issues appear very rarely in the documents at the local level.

- This is insufficient for the implementation of the objectives of public health policy.

- Health inequality representation is insufficient regarding Health in all Policies

\section{Conflict of interest}

The authors declare they have no conflicts of interest. 


\section{REFERENCES}

1.Indulski JA, Leowski J. Podstawy medycyny społecznej. Państwowy Zakład Wydawn. Lekarskich, 1971.

2.Ståhl T, Wismar M, Ollila E, et al. Health in all policies. Prospects and potentials. Helsinki: Finnish Ministry of Social Affairs and Health and Health and European Observatory on Health Systems and Policies, 2006.

3. Declaration Health In All Policies. Rome, 18 December 2007. http://www. publichealth.ie/files/file/DECLARATION_ADOPTED_SIGNATURES. pdf (access: 27.11.2020).

4. Ustawa z dnia 6 grudnia 2006 r. o zasadach prowadzenia polityki rozwoju. DzU 2006 nr 227 poz. 1658, (2006).

5. Swayne LE, Duncan WJ, Ginter PM. Strategic Management of Health Care Organizations 5Th Ed. MA Blackwell Publishing Ltd, 2006.

6. Dimova A, Rohova M, Hasardzhiev S, et al. An innovative approach to participatory health policy development in Bulgaria: The conception and first achievements of the Partnership for Health. Health Policy. 2018; 122(2): 81-86. https://doi.org/10.1016/j.healthpol.2017.11.002

7. Hofstad H. The ambition of Health in All Policies in Norway: The role of political leadership and bureaucratic change. Health Policy. 2016; 120(5): 567-575. https://doi.org/10.1016/j.healthpol.2016.03.001
8. Social inequalities in health in Poland, the WHO report, 2012 euro.who. int/ data/assets/pdf file/0008/177875/E96720.pdf (access: 27.11.2020)

9. Implementation of health policy programmes by the territorial selfgovernment units. Information on audit results. SAO 2016. https:// www.SAO.gov.pl/kontrole/P/15/063/. (access: 27.11.2020)

10. Leśniewska A, Posobkiewicz M, Kanecki K, et al. Działania powiatów w zakresie profilaktyki i promocji zdrowia w Polsce - w świetle badan ankietowych. Hygeia Public Health. 2014; 49(3): 472-477.

11. Wojtyniak B, Rabczenko D, Pokarowski P, et al. Atlas umieralności ludności Polski w latach 1999-2001 i 2008-2010 - wydanie internetowe; http://atlas.pzh.gov.pl. (dostęp: 27.11.2020).

12. Smętkowski M, Gorzelak G, Płoszaj A, et al. Powiaty zagrożone deprywacją: stan, trendy i prognoza, Raporty i analizy EUROREG NR 7/2015; Centrum Europejskich Studiów Regionalnych i Lokalnych EUROREG, 2015. http://www.euroreg.uw.edu.pl/dane/web_euroreg publications_files/5529/powiatowy_indeks_deprywacji_2015.pdf (dostep 27.11.2020)

13. Wojtyniak B, Mazur J. Społeczne nierówności w zdrowiu dzieci i młodzieży w Polsce w świetle badań populacyjnych. Narodowy Instytut Zdrowia Publicznego, 2016. http://bazawiedzy.pzh.gov.pl/nierownosciw-zdrowiu, (dostęp: 27.11.2020). 